\title{
Are all customers really the same? Comparing service quality and satisfaction between residential and business telecommunications customers
}

Authors:
Charles Makanyeza ${ }^{1}$
Darlington Mumiriki
Affiliations:
'Department of Marketing,
School of Entrepreneurship \&
Business Sciences, Chinhoyi
University of Technology,
Zimbabwe
'TelOne, Harare, Zimbabwe
Corresponding author:
Charles Makanyeza,
cmakanyeza@yahoo.co.uk
Dates:
Received: 21 Sept. 2015
Accepted: 22 Feb. 2016
Published: 10 June 2016
mobile device
to read online.
How to cite this article:
Makanyeza, C., Mumiriki, D.,
2016, 'Are all customers
really the same? Comparing
service quality and
satisfaction between
residential and business
telecommunication
customers', Acta Commercii
16(1), a348. http://dx.doi.
org/10.4102/ac.v16i1.348
Copyright:
C 2016. The Authors.
Licensee: AOSIS. This work
is licensed under the
Creative Commons
Attribution License.

Orientation: The study focused on the moderating role of the type of customer on the relationship between service quality and customer satisfaction.

Research purpose: The study sought to examine differences in the relationship between service quality and customer satisfaction because of the type of customer.

Motivation for the study: Previous studies have not examined the relationship between service quality and customer satisfaction between residential and business customers.

Research design, approach and method: The study used a cross-section of 203 customers (108 residential and 95 business) in the fixed-line telecommunications sector in Zimbabwe. Moderated regression analysis was performed to test the research hypotheses.

Main findings: It was established that the customer category (residential versus business) does not moderate the effect of service quality on customer satisfaction. Practical/managerial implications are, generally, that it is not necessary to segment customers by customer category (residential versus business) when managing service quality to achieve customer satisfaction.

Contribution/value add: The main theoretical contribution of the study is the comparison of the effect of service quality on customer satisfaction between residential and business customers.

\section{Introduction}

Despite increased interest in the study of service quality and customer satisfaction (Baumann et al. 2007; Beneke et al. 2012; De Jagger \& Du Plooy 2006, 2007; Ha \& Son 2014; Kuo, Wu \& Deng 2009; Seth, Deshmukh \& Vrat 2005; Thaichon et al. 2014; Wang \& Shieh 2006), to date no study in the public domain has compared the effect of service quality on customer satisfaction between business to business (B2B) and business to consumer (B2C) markets. Furthermore, the effect of the individual dimensions of service quality (namely tangibility, reliability, responsiveness, assurance and empathy) on customer satisfaction has not been given much scholarly attention (Aghdaie \& Faghani 2012; Baumann et al. 2007; Wang \& Shieh 2006). Therefore, this study sought to determine the effect of perceived service quality on customer satisfaction, to determine the effect of the individual dimensions of perceived service quality on customer satisfaction, and to compare the findings between residential (B2C) and business (B2B) customers. Thus, the article makes a substantial contribution to the current body of knowledge by comparing the effect of service quality on customer satisfaction between residential and business customers.

A good understanding of the behaviour of various market segments is invaluable in that it can be used to make decisions about target markets (Brennan et al. 2011; Kotler et al. 2008). One of the many approaches that can be used to segment markets is to divide the market based on the purpose for which customers buy products. In this regard, markets can be divided into two major categories called B2B and B2C markets (Hutt \& Speh 2012; Kumar \& Sareen 2011). Customers in B2C markets purchase products and services from sellers for end use whilst in B2B markets, organisational customers buy products and services from sellers for use in the production of other products and services (Brennan et al. 2011; Ellis 2011; Hutt \& Speh 2012; Kumar \& Sareen 2011).

Service quality is a multi-dimensional construct that comprises tangibility, reliability, responsiveness, assurance and empathy (Aghdaie \& Faghani 2012; Baumann et al. 2007; Coetzee, Van Zyl \& Taite 2013; De Jagger \& Du Plooy 2007; Wang \& Shieh 2006). Inconsistent findings as regards the effect of each of the dimensions of service quality on customer satisfaction were 
reported in a few studies in which this phenomenon has been investigated (Aghdaie \& Faghani 2012; Baumann et al. 2007; Wang \& Shieh 2006). Thus, it is plausible to expect that the relationship between each of the dimensions of service quality and customer satisfaction will be different. This is conceivable because these dimensions refer to different aspects of service quality which are capable of being managed in isolation (Agyapong 2011). For example, a firm can do better in terms of managing certain dimensions of service quality than others.

Data from the fixed-line telecommunications industry in Zimbabwe were used because prior research on service quality and customer satisfaction has neglected this sector (Almossawi 2012; Baumann et al. 2007; Khuhro et al. 2011; Nimako et al. 2010; Wang \& Shieh 2006). As such, it is envisaged that the findings of the study would enhance an understanding of the effect of perceived service quality on customer satisfaction across different sectors of the economy. According to Agyapong (2011), the telecommunications sector plays an important role in any economy. It facilitates transactions, aids in decision making, promotes business and interpersonal relationships, and enables exchange of information.

The significance of the study is two-pronged. Firstly, a good understanding of the differences between the two customer categories is critical in that it allows fixed-line telecommunications operators to craft effective marketing programmes for each of the customer segments (Brennan et al. 2011; Kotler et al. 2008). Secondly, a comprehensive understanding of the effects of individual dimensions of service quality on customer satisfaction is pertinent because it assists service providers to decide on which dimensions they should concentrate their effort on in various market segments (Aghdaie \& Faghani 2012; Agyapong 2011).

\section{Study context}

The telecommunications sector in Zimbabwe is dominated by a few large firms. TelOne used to be the only major operator in Zimbabwe's telecommunications sector. With the passage of time, new players came in to take advantage of the untapped mobile telecommunications sector. Currently, the telecommunications sector in Zimbabwe is made up of fixed-line and mobile operators. The single major player in the fixed-line telecommunications sector is TelOne whilst the three major players in the mobile telecommunications sector are Econet, Net One and Telecel (Kabweza 2010). The introduction of other players in Zimbabwe's telecommunications sector increased competition so much that it has become inevitable to study consumer behaviour with the motive to understand how consumers perceive the quality of services offered by the service providers and whether or not they are satisfied with the services. Despite this increased competition, the fixed-line telecommunications sector has remained relevant to the sector because of its low tariffs.

\section{Literature review, hypotheses and conceptual framework Residential versus business customers}

Market segmentation is an important aspect of a successful marketing effort. It involves dividing the market into distinct subsets or groups of customers on the basis of needs, characteristics or behaviour, and then selecting one or more segments to target with a specific marketing mix (Kotler et al. 2008). Hutt and Speh (2012) and Kumar and Sareen (2011) suggest that customers may be divided into two major categories based on the type of business, namely B2C and B2B.

B2C marketing is concerned with transactions conducted between a firm and end-user consumers. Customers involved in B2C transactions purchase products and services for end use (Hutt \& Speh 2012; Kumar \& Sareen 2011). In the context of this article, residential customers represent B2C customers, that is, customers who utilise telecommunications services to meet their personal needs.

In B2B marketing, the customer is an organisation rather than an individual as is the case in B2C marketing (Brennan et al. 2011). B2B transactions are conducted between firms or businesses when firms purchase products and services from other firms for use in manufacturing products and services for sale (Hutt \& Speh 2012; Kumar \& Sareen 2011). Thus Brennan et al. (2011:6) refer to B2B marketing as '... marketing of goods and services to organisations'. The term $B 2 B$ marketing has replaced the older term industrial marketing (Brennan et al. 2011; Ellis 2011). In this article, business customers represent $B 2 B$ customers, that is, customers who utilise telecommunications services as an input into the production of products and services for sale to other customers.

\section{Perceived service quality}

It is generally agreed that service quality means different things to different people (Beneke et al. 2012; Lovelock \& Wirtz 2011; Tam 2004). However, Tam (2004) acknowledges that there is a general consensus amongst academics that service quality should be defined from a customer's perspective. In this regard, service quality is referred to as perceived service quality. Thus, Lovelock and Wirtz (2011:406) define service quality from the user's perspective as '... consistently meeting or exceeding customer expectations'. In the article, perceived service quality is, therefore, construed as the extent to which customers perceive that telecommunications services meet their expectations.

Service quality comprises five dimensions, namely, tangibility (tangibles), reliability, responsiveness, assurance and empathy (Lovelock \& Wirtz 2011; Wang \& Shieh 2006). Tangibility refers to physical facilities, written materials or the appearance of the service firm's personnel (Lovelock \& Wirtz 2011; Wang \& Shieh 2006; Zeithaml, Bitner \& Gremler 2012). Reliability means delivering service to customers as promised in a dependable and accurate manner (De Jagger \& Du Plooy 2007; Lovelock \& Wirtz 2011). Responsiveness 
assesses the willingness of a company to help customers and/or to deliver prompt service (Coetzee et al. 2013; De Jagger \& Du Plooy 2007; Lovelock \& Wirtz 2011). Assurance describes the knowledge and courtesy of staff that makes customers feel assured and confident (Wang \& Shieh 2006). Coetzee et al. (2013) point out that empathy refers to a firm's ability to care for and provide personalised attention to customers.

The success of service-oriented firms is largely dependent on improvements in service quality (Coetzee et al. 2013; Thaichon et al. 2014). Thus, service organisations should meet the requirements of their customers whilst sustaining competitive advantage (Thaichon et al. 2014). Aghdaie and Faghani (2012) suggest that the provision of service quality is a key consideration for planning marketing programmes. According to Coetzee et al. (2013), superior service quality creates value for business, and also leads to customer satisfaction, repeat purchase and, ultimately, customer loyalty. On the other hand, a firm can use the provision of superior service quality as a competitive advantage in today's highly globalised, industrialised and competitive markets (Aghdaie \& Faghani 2012; Coetzee et al. 2013; Thaichon et al. 2014). Concurring, Lovelock and Wirtz (2011) emphasise that poor service quality places the firm at a competitive disadvantage, implying that poor service delivery may drive away customers.

\section{Customer satisfaction}

There are as many attempts to define customer satisfaction as there are scholars. Despite these attempts, there still does not appear to be an agreed-upon definition of customer satisfaction (Beneke et al. 2012; De Jagger \& Du Plooy 2007; Ha \& Son 2014). According to Kuo et al. (2009), customer satisfaction refers to the customer's total response to the purchase experiences of a particular product, that is, the total consumption perception of consumers when using services. Lovelock and Wirtz (2011:623) describe satisfaction as '... a person's feeling of pleasure or disappointment resulting from a consumption experience when comparing a product, perceived performance or outcome in relation to his or her expectation'. If the product's performance falls short of expectations, the buyer is dissatisfied. If performance matches expectations, the customer is said to be satisfied. If performance exceeds expectations, the buyer is delighted (Bashir, Machali \& Mwinyi 2012). The operational definition of customer satisfaction in the article is, therefore, given as the extent to which a customer is pleased or disappointed as a result of the consumption experience of the telecommunications service.

Tam (2004) views customers as the primary source of most firms' revenues. As such, customer satisfaction, as a construct, has attracted much attention from scholars and marketers for the past few decades. More and more, satisfaction is considered as important for the success of any organisation in today's increasingly competitive business environment (Beneke et al. 2012; De Jagger \& Du Plooy 2007; Moolman 2011; Thaichon et al. 2014). Customer satisfaction in the organisation is important; it enables organisations to achieve competitive advantage (Thaichon et al. 2014). The outcomes of customer satisfaction include repeat purchase, increased sales, cost reduction and positive word-of-mouth recommendation. These, in turn, enhance the profitability of the firm. It is more expensive to recruit new customers than to retain existing ones. In addition, satisfied customers usually refer the company and its products to other customers (Olorunniwo et al. 2006). This makes customer satisfaction a key consideration in the design of marketing programmes (Homburg, Koschate \& Hoyer 2005).

\section{Service quality and customer satisfaction}

Service quality is an antecedent to customer satisfaction (Agyapong 2011; Coetzee et al. 2013; Thaichon et al. 2014). Several studies have reported that service quality positively influences customer satisfaction (Arasli, Katircioglu \& Mehtap-Smadi 2005; Lee \& Hwan 2005; Thaichon et al. 2014; Kuo et al. 2009).

The study of the effect of each of the dimensions of service quality on customer satisfaction has not received much scholarly attention (Aghdaie \& Faghani 2012; Baumann et al. 2007; Wang \& Shieh 2006). Notably, all dimensions were found to significantly influence customer satisfaction in two studies (Baumann et al. 2007; Wang \& Shieh 2006) whilst only four dimensions, namely tangibility, reliability, responsiveness and empathy were found to significantly influence customer satisfaction in another study (Aghdaie \& Faghani 2012).

\section{Differences between residential (B2C) and business (B2B) customers}

Buying behaviour in $\mathrm{B} 2 \mathrm{~B}$ and $\mathrm{B} 2 \mathrm{C}$ markets tends to differ because of differences in the characteristics between B2B and B2C buyers (Brennan et al. 2011; Ellis 2011). Table 1 summarises the main differences between residential and business customers.

\section{Hypotheses development and conceptual framework}

Table 1 shows that there are stronger relationships in $\mathrm{B} 2 \mathrm{~B}$ than in B2C marketing. As such, it is expected that there are stronger ties between the firm and business customers than residential customers. As echoed by Brennan et al. (2011) and Stokes and Lomax (2008), sellers should provide business solutions to B2B customers. Likewise, sellers should provide quality products or services that can be used in the production of goods and services by other firms. This calls for sellers to give more specific attention to the requirements of business customers in B2B marketing than they do to customers in B2C marketing. The provision of quality products or services in the form of inputs that satisfy the needs of business customers is a prerequisite for a firm's success. For a sustainable strong relationship to exist it is expected that the seller must continually provide quality products or services that at least meet B2B customer expectations. It is, therefore, conceivable to expect the relationship between service quality and customer satisfaction to be stronger in B2B than 
TABLE 1: Main differences between residential (B2C) and business (B2B) customers.

\begin{tabular}{lll}
\hline Characteristic & Residential (B2C) customers & Business (B2B) customers \\
\hline Buyers & $\begin{array}{l}\text { Buying is usually performed by } \\
\text { professionally trained people }\end{array}$ & $\begin{array}{l}\text { Buying is usually performed by lone individuals } \\
\text { who are not professionally trained to do so }\end{array}$ \\
$\begin{array}{l}\text { Number of people involved in buying } \\
\text { decision making }\end{array}$ & Many & Few \\
$\begin{array}{l}\text { Complexity of buying process } \\
\text { Concentration of customers }\end{array}$ & Complex & Simple \\
$\begin{array}{l}\text { Buying power } \\
\text { Rationality of buying decisions }\end{array}$ & Concentrated & Many customers buy as isolated individuals \\
$\begin{array}{l}\text { Strength of relationship between } \\
\text { the firm and its customers }\end{array}$ & More rational & Low \\
Marketing mix customisation & Usually strong & Less rational \\
Transaction values & High; Products are less standardised & Usually weak \\
Marketing communication techniques & Typically high & Low; products are more standardised \\
\hline
\end{tabular}

Source: Adapted from Brennan et al. (2011) and Ellis (2011)

in B2C markets. In this regard, the following hypotheses were posited:

- H1. The effect of service quality on customer satisfaction will be higher for business than residential customers.

- H2. The effect of tangibility on customer satisfaction will be higher for business than residential customers.

- H3. The effect of reliability on customer satisfaction will be higher for business than residential customers.

- H4. The effect of responsiveness on customer satisfaction will be higher for business than residential customers.

- H5. The effect of assurance on customer satisfaction will be higher for business than residential customers.

- H6. The effect of empathy on customer satisfaction will be higher for business than residential customers.

Based on the research hypotheses, the conceptual framework of the study is presented in Figure 1.

\section{Research method and design Research design and approach}

A cross-sectional survey of customers was carried out in Harare, the capital city of Zimbabwe in 2013 using selfadministered questionnaires. A quantitative approach was adopted.

\section{Research participants and sampling procedure}

TelOne was the single major player in the fixed telecommunications sector in Zimbabwe. As such, the sample was drawn from TelOne's customer directory. The total number of active customers in Harare was estimated at 108 000, that is, 84000 residential and 24000 business customers. One hundred and twenty five questionnaires were randomly distributed to each of the two customer categories, namely residential and business customers in person. This resulted in a sample size of 250. Surveys were distributed in person.

Out of the 250 questionnaires distributed, 203 were returned and usable (108 and 95 questionnaires from residential and business customers respectively). This represents a response rate of $86.4 \%$ for residential customers, $76 \%$ for business customers and an overall response rate of $81.2 \%$. The relatively lower response in the business compared to the residential customer category was attributed to work commitments and adherence to company policy in that some businesses required

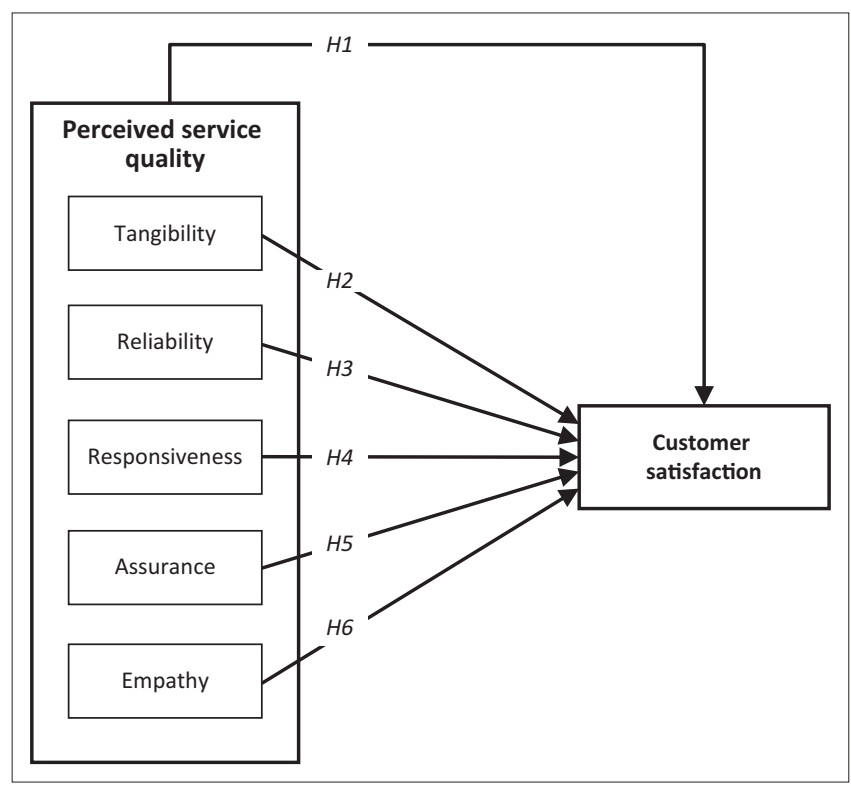

Source: Authors' own work

FIGURE 1. Conceptual framework depicting the relationship between the dimensions of service quality and customer satisfaction.

internal departmental approval for data to be collected. Lower response rate is a common phenomenon in B2B market research (Iyer, Germain \& Frankwick 2004; Quaddus \& Hofmeyer 2007). The profile of the sample is presented in Table 2.

As shown in Table 2, the sample was dominated by males for both customer categories. The majority of the respondents were between 25 and 50 years. Results show that the fixed-line telecommunications sector mainly offers voice/telephone services.

\section{Questionnaire design}

The questionnaire was divided into three sections, namely general information about the respondents, service quality, and customer satisfaction. Perceived service quality was measured using 25 items (five items for each of the five dimensions) on a Likert scale ranging from 1 ('strongly disagree') to 7 ('strongly agree'). The items are presented in Appendix 1. The items were adopted from literature (Coetzee et al. 2013; Cronin \& Taylor 1992, 1994; Kuo et al. 2009; 
Olorunniwo et al. 2006; Wang \& Shieh 2006) and modified to suit the present study. Customer satisfaction was measured using six items on a Likert scale anchored by 1 ('strongly disagree') and 7 ('strongly agree') as shown in Appendix 1. The items were adopted from Ha and Son (2014), Kuo et al. (2009), Tam (2004) and Thaichon et al. (2014) and modified to suit the context of this study.

TABLE 2: Profile of the sample.

\begin{tabular}{lccc}
\hline Attribute & \multicolumn{3}{c}{ Percent (\%) } \\
\cline { 2 - 4 } & $\begin{array}{c}\text { Residential customers } \\
(\boldsymbol{n}=\mathbf{1 0 8})\end{array}$ & $\begin{array}{c}\text { Business customers } \\
(\boldsymbol{n}=\mathbf{9 5})\end{array}$ & $\begin{array}{c}\text { Overall } \\
(\boldsymbol{n}=\mathbf{2 0 3})\end{array}$ \\
\hline Gender & & & \\
Male & 68.5 & 63.2 & 66.0 \\
Female & 31.5 & 36.8 & 34.0 \\
Age & & & \\
Below 25 years & 12.0 & 4.2 & 8.4 \\
25-30 years & 21.3 & 28.4 & 24.6 \\
31-40 years & 24.1 & 42.1 & 32.5 \\
41-50 years & 27.8 & 24.2 & 26.1 \\
Above 50 years & 14.8 & 1.1 & 8.4 \\
Main type of service & & & \\
Voice/telephone & 72.2 & 58.9 & 66.0 \\
Internet/ADSL & 22.2 & 33.7 & 27.6 \\
Data & 4.6 & 6.3 & 5.4 \\
Other & 0.9 & 1.1 & 1.0 \\
\hline
\end{tabular}

Source: Authors' own work

\section{Analysis and results Validity and reliability}

Exploratory factor analysis (EFA) was conducted to determine the factors emerging from the data. Before conducting EFA, data were tested for sampling adequacy and whether or not they permitted EFA to be executed using Kaiser-Meyer-Olkin Measure of Sampling Adequacy (KMO) and the Bartlett's Test of Sphericity, respectively. It was found that the sample was adequate and that data permitted EFA to be conducted $(\mathrm{KMO}=0.96$; approx. Chi-Square $=2$ 980.23; degrees of freedom $=465 ; p<0.001)$. This follows Field (2009)'s recommendations that the $\mathrm{KMO}$ statistic close to 1 denotes that the sample is adequate and that a significant $(p<0.05)$ Bartlett's test shows that factor analysis can be executed. Then, EFA was conducted. As expected, the solution gave six factors, related to the five dimensions of service quality as well as satisfaction as shown in Table 3.

As shown in Table 3 all factor loadings and item-total correlations met minimum expectations as suggested by Field (2009) that loadings of at least 0.4 and item-total correlations of at least 0.3 are sufficient. All scales displayed acceptable reliabilities as indicated by Cronbach's $\alpha$ ranging between 0.70 and 0.92. According to Bryman (2008) and

TABLE 3: Summary of validity and reliability statistics.

\begin{tabular}{|c|c|c|c|c|c|c|}
\hline Scale & Item & Factor loading & Item-total correlation & Cronbach's $\alpha$ & Mean & Standard deviation \\
\hline \multirow[t]{5}{*}{ Tangibility } & TAN1 & 0.65 & 0.62 & - & 4.30 & 1.56 \\
\hline & TAN2 & 0.73 & 0.68 & - & 4.11 & 1.69 \\
\hline & TAN3 & 0.69 & 0.66 & 0.70 & 4.69 & 1.55 \\
\hline & TAN4 & 0.88 & 0.77 & - & 4.87 & 1.60 \\
\hline & TAN5 & 0.61 & 0.57 & - & 3.66 & 1.89 \\
\hline \multirow[t]{5}{*}{ Reliability } & REL1 & 0.81 & 0.75 & - & 3.97 & 1.85 \\
\hline & REL2 & 0.78 & 0.71 & - & 4.72 & 1.73 \\
\hline & REL3 & 0.73 & 0.68 & 0.84 & 4.51 & 1.60 \\
\hline & REL4 & 0.69 & 0.66 & - & 4.17 & 2.84 \\
\hline & REL5 & 0.67 & 0.63 & - & 4.20 & 1.86 \\
\hline \multirow[t]{4}{*}{ Responsiveness } & RES1 & 0.64 & 0.61 & - & 4.30 & 1.75 \\
\hline & RES2 & 0.67 & 0.63 & - & 4.28 & 1.74 \\
\hline & RES3 & 0.73 & 0.68 & 0.83 & 4.82 & 1.70 \\
\hline & RES4 & 0.71 & 0.67 & - & 4.46 & 1.70 \\
\hline \multirow[t]{7}{*}{ Assurance } & ASS1 & 0.77 & 0.70 & - & 4.53 & 1.63 \\
\hline & ASS2 & 0.67 & 0.63 & - & 5.18 & 1.55 \\
\hline & ASS3 & 0.78 & 0.71 & 0.76 & 5.02 & 1.46 \\
\hline & ASS4 & 0.66 & 0.62 & - & 4.99 & 1.55 \\
\hline & ASS5 & 0.64 & 0.61 & - & 3.80 & 1.78 \\
\hline & EMP1 & 0.74 & 0.69 & - & 4.92 & 1.48 \\
\hline & EMP2 & 0.78 & 0.71 & - & 4.83 & 1.61 \\
\hline \multirow[t]{5}{*}{ Empathy } & EMP3 & 0.77 & 0.70 & 0.83 & 4.69 & 1.55 \\
\hline & EMP4 & 0.61 & 0.57 & - & 4.47 & 1.71 \\
\hline & EMP5 & 0.60 & 0.56 & - & 4.47 & 1.74 \\
\hline & SAT1 & 0.78 & 0.71 & - & 4.89 & 1.80 \\
\hline & SAT2 & 0.81 & 0.75 & - & 4.89 & 1.71 \\
\hline \multirow[t]{2}{*}{ Satisfaction } & SAT3 & 0.84 & 0.76 & 0.92 & 4.85 & 1.83 \\
\hline & SAT4 & 0.83 & 0.76 & - & 5.02 & 1.78 \\
\hline
\end{tabular}


Zikmund et al. (2010), a Cronbach's $\alpha$ of at least 0.60 represents an acceptable level of reliability.

To be certain about validity, squared inter-construct correlations (SICs) and average variance extracted (AVE) were assessed. The results are presented in Table 4 .

According to Fornell and Larcker (1981), there are two conditions that must be met in order to be sure about validity. Firstly, AVE should be greater than 0.5. Secondly, AVE should be greater than the corresponding SICs. Results in Table 4 show that AVE values range between 0.51 and 0.67 and that the values are greater than SICs in each case. Hence, the two conditions are satisfied and it can be said that the measures were valid.

\section{Hypothesis testing}

Moderated regression analysis was used to test H1. The results are presented in Table 5 .

Results from Table 5 show that service quality has a positive effect $(\beta=0.73, t=13.03, p<0.001)$ on customer satisfaction. The analysis of the interaction term (service quality $\times$ customer category) shows that customer category does not moderate the effect of service quality on customer satisfaction $(\beta=0.06$, $t=1.12, p=0.27)$. Therefore, $H 1$ is not supported.

Moderated multiple regression analysis was used to test $H 2$, H3, H4, H5 and H6. The results are presented in Table 6.

As shown in Table 6 , the $\beta$ and $t$ values associated with tangibility, reliability and responsiveness were not statistically significant $(p>0.05$ in each case). This suggests that these dimensions do not influence customer satisfaction. Results reveal that assurance $(\beta=0.27, t=3.08, p=0.003)$ and empathy $(\beta=0.29, t=3.24, p<0.001)$ positively influence customer satisfaction. The $\beta$ and $t$ values associated with interaction terms, namely tangibility $\times$ customer category, reliability $\times$ customer category, responsiveness $\times$ customer category, and assurance $\times$ customer category were not statistically significant ( $p>0.05$ in each). This implies that customer category does not moderate the effect of tangibility, reliability, responsiveness and assurance on customer satisfaction. Therefore, $\mathrm{H2}, \mathrm{H} 3, \mathrm{H} 4$ and $H 5$ are not supported. The analysis of $\beta$ and $t$ values associated with the interaction term empathy $\times$ customer category shows that customer category moderates the effect of empathy on customer satisfaction $(\beta=-0.18, t=-2.01, p=0.03)$. To demonstrate how the nature of customer category (that is residential versus business category) moderates the relationship between empathy and customer satisfaction, simple slopes for standardised values of customer satisfaction were plotted. Figure 2 presents the relationship between empathy and customer satisfaction at business $(z=-1)$ and residential $(z=1)$ categories of customers. These slopes were derived from $\beta$ values.

According to Figure 2, standardised empathy has a positive effect on standardised customer satisfaction. However, the effect of standardised empathy on standardised customer satisfaction is stronger for business than for residential customers. Therefore, H6 is supported. This suggests that the effect of empathy on customer satisfaction depends on the nature of the customer.

\section{Discussion}

It was demonstrated that perceived service quality has a positive influence on customer satisfaction in the fixed-line telecommunications in Zimbabwe. This finding is in line

TABLE 5: Moderated regression analysis.

\begin{tabular}{lcc}
\hline Variable & $\boldsymbol{\beta}$ & $\boldsymbol{t}$ \\
\hline Service quality & 0.73 & $13.03^{*}$ \\
Customer category & -0.03 & $-0.52^{* *}$ \\
Service quality $\times$ Customer category & 0.06 & $1.12^{* *}$ \\
\hline
\end{tabular}

Source: Authors' own work

$R$ square $=0.55 ; F=58.74 ; p<0.001$

Dependant variable: Satisfaction.

Predictors: Service quality, Customer category, Service quality $\times$ Customer category.

$*, p \leq 0.001 ; * *, p>0.05$

TABLE 6: Moderated multiple regression analysis.

\begin{tabular}{lcc}
\hline Variable & $\boldsymbol{\beta}$ & $\boldsymbol{T}$ \\
\hline Tangibility & 0.13 & $1.60^{* * * *}$ \\
Reliability & 0.11 & $1.26 * * * *$ \\
Responsiveness & 0.05 & $0.51^{* * * *}$ \\
Assurance & 0.27 & $3.08^{* *}$ \\
Empathy & 0.29 & $3.24 * * *$ \\
Customer category & -0.03 & $-0.51^{* * * *}$ \\
Tangibility $\times$ Customer category & 0.06 & $0.74^{* * * *}$ \\
Reliability $\times$ Customer category & 0.15 & $1.70^{* * * *}$ \\
Responsiveness $\times$ Customer category & -0.02 & $-0.16^{* * * *}$ \\
Assurance $\times$ Customer category & 0.07 & $0.79 * * * *$ \\
Empathy $\times$ Customer category & -0.18 & $-2.01 *$ \\
\hline
\end{tabular}

Source: Authors' own work

$R$ square $=0.59 ; F=17.80 ; p<0.001$

Dependant variable: Satisfaction.

Predictors: Tangibility, Reliability, Responsiveness, Assurance, Empathy, Customer category, Tangibility $\times$ Customer category, Reliability $\times$ Customer category, Responsiveness $\times$ Customer category, Assurance $\times$ Customer category, Empathy $\times$ Customer category.

$*, p \leq 0.05 ; * *, p \leq 0.01 ; * * *, p \leq 0.001 ; * * * *, p>0.05$

TABLE 4: Mean, standard deviation, SICs and AVE.

\begin{tabular}{|c|c|c|c|c|c|c|c|c|c|}
\hline Factor & Mean & SD & QUAL & TAN & REL & RES & ASS & EMP & SAT \\
\hline Service quality (QUAL) & 4.47 & 1.66 & 0.55 & - & - & - & - & - & - \\
\hline Tangibles (TAN) & 4.33 & 1.66 & 0.49 & 0.57 & - & - & - & - & - \\
\hline Reliability (REL) & 4.31 & 1.98 & 0.44 & 0.27 & 0.59 & - & - & - & - \\
\hline Responsiveness (RES) & 4.38 & 1.75 & 0.48 & 0.3 & 0.3 & 0.51 & - & - & - \\
\hline Assurance (ASS) & 4.7 & 1.59 & 0.41 & 0.21 & 0.27 & 0.36 & 0.55 & - & - \\
\hline Empathy (EMP) & 4.68 & 1.62 & 0.43 & 0.24 & 0.29 & 0.35 & 0.4 & 0.54 & - \\
\hline
\end{tabular}

Source: Authors' own work

Note: Diagonal elements in bold represent AVE; SD denotes standard deviation. 


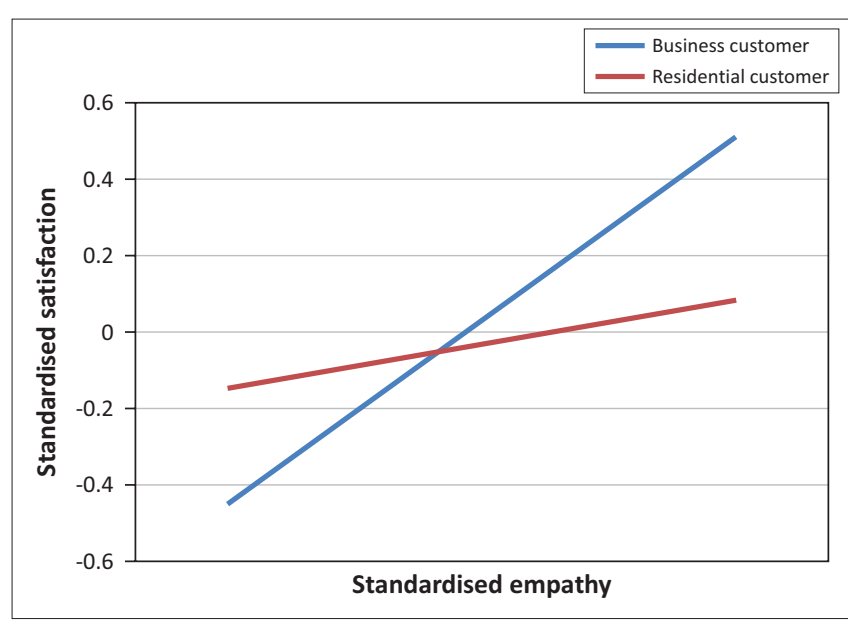

Source: Authors' own work

FIGURE 2. Simple slopes for standardised empathy on standardised satisfaction at business and residential customer categories.

with the view by Baumann et al. (2007), Coetzee et al. (2013), Kuo et al. (2009), Tam (2004) and Wang and Shieh (2006) that perceived service quality has a positive effect on customer satisfaction. Zeithaml et al. (2012) concur that customers perceive services in terms of quality and how satisfied they are with their experience. When customers perceive the service quality to be high, they are likely to be satisfied with the fixed-line telecommunications service offering.

The article revealed that only two dimensions of service quality (assurance and empathy) positively influence customer satisfaction. Tangibility, reliability and responsiveness do not significantly influence customer satisfaction. This implies that, although overall perceived service quality significantly influences customer satisfaction in the fixed-line telecommunications sector, only the assurance and empathy dimensions make a significant contribution to this relationship. Zeithaml et al. (2012) suggest that assurance is crucial for services that customers perceive to be risky and in which customers are uncertain about their ability to evaluate outcomes. On the other hand, empathy ensures that customers feel valued and their needs are cared for by the service provider. However, the fixed-line telecommunications sector is not inherently associated with risk such as that found in the banking or medical sectors. The significance of assurance and empathy in the present study could be historical. Zimbabwe's economy had been on the downturn for more than a decade until 2009 when multi-currencies were adopted (Noko 2011; Sikwila 2013). During this period, service delivery from many sectors, including fixed-line telecommunications, deteriorated. Even if customers paid for the services, there was no guarantee that they were going to obtain the desired service. Service providers lost 'touch' with their customers as the needs of customers were no longer being understood and treated in a special way. In short, there was a lack of assurance and empathy from the service providers. As such, consumers lost confidence in the service delivery system to the extent that it became risky to pay for utilities because money could be lost. Perhaps this explains why assurance and empathy each significantly influenced customer satisfaction in the fixed-line telecommunications sector of Zimbabwe, a developing and transitional economy.

This article demonstrated that the customer category (residential versus business) does not influence the effect of service quality on customer satisfaction. This implies that the extent to which service quality positively influences customer satisfaction is the same for both residential and business customers. Similarly, it is demonstrated that the customer category does not moderate the effect of tangibility, reliability, responsiveness and assurance on customer satisfaction. This shows that the effect of tangibility, reliability, responsiveness and assurance on customer satisfaction is the same for residential and business customers in the Zimbabwe's telecommunications industry. However, the nature of the customer moderates the effect of empathy on customer satisfaction. This suggests that the positive effect of empathy on customer satisfaction is stronger for business than for residential customers, and that business customers tend to be satisfied with empathy, that is, they want to feel valued and their needs cared for by service providers (Brennan et al. 2011; Ellis 2011). For business customers, buying is a way of solving business problems (Brennan et al. 2011). As such, professional buying and the high bargaining power of business customers (Brennan et al. 2011; Ellis 2011; Stokes \& Lomax 2008) enable them to demand personalised attention from service providers, thus making the relationship between empathy and customer satisfaction stronger for business than for residential customers.

\section{Theoretical contribution}

The article enhances our understanding of the effect of perceived service quality on customer satisfaction. In this regard, researchers may benefit from the findings of the article.

It adds to the existing literature (Aghdaie \& Faghani 2012; Baumann et al. 2007; Coetzee et al. 2013; Kuo et al. 2009; Tam 2004; Thaichon et al. 2014; Wang \& Shieh 2006) perceiving that service quality has a positive effect on customer satisfaction. Whilst there is no consensus on individual effects of the dimensions of service quality on customer satisfaction (Aghdaie \& Faghani 2012; Baumann et al. 2007; Wang \& Shieh 2006), the article adds to the ongoing debate. Of the five dimensions of service quality, only assurance and empathy have been found to have a significant positive effect on customer satisfaction in the fixed-line telecommunications sector.

The major contribution that the article makes to the current body of knowledge is the comparison of the findings between residential and business customer segments. Generally, the influence of perceived service quality on customer satisfaction does not differ between residential and business customers. The only difference is with respect to a dimension of service quality, namely empathy, the positive effect of which on customer satisfaction is stronger for business than for residential customers. 


\section{Managerial implications}

Perceived service quality was found to influence customer satisfaction positively. This implies that fixed-line telecommunications service providers should aim to provide high quality service, as this would increase customer satisfaction. Thus, service delivery should strive to meet the needs, wants and expectations of customers. As satisfaction increases, fixed-line telecommunications service providers are expected to benefit in terms of repeat purchase (Thaichon et al. 2014). Apart from increasing the firm's revenue, repeat purchase leads to customer loyalty (Homburg et al. 2005). Loyal customers recommend the firm and its products to other consumers. Furthermore, loyal customers are not easily tempted to switch to competitors' products. Keeping loyal customers results in lower marketing and operational costs than does recruiting new customers (Olorunniwo et al. 2006). As a result, the firm's profit increases (Homburg et al. 2005; Olorunniwo et al. 2006; Thaichon et al. 2014).

Service practitioners should also pay attention to the dimensionality of service quality when planning marketing programmes in the fixed-line telecommunications sector in developing and transitional economies such as Zimbabwe. Only assurance and empathy were found to have a significant influence on customer satisfaction. Therefore, service providers should focus more on perceived assurance and empathy in order to increase customer satisfaction. Assurance would give customers some sort of guarantee of dependable service delivery (Wang \& Shieh 2006) whilst empathy would ensure that customers feel honoured to be a part of the service provider's clientele (Coetzee et al. 2013). Assurance and empathy lead to customer satisfaction, which, in turn, is likely to lead to customer loyalty through repeat purchase and positive word-of-mouth recommendation (Coetzee et al. 2013; Wang \& Shieh 2006). To improve assurance, service providers should train their employees to be courteous. Employees should also be trained in such a way that they can instil trust and confidence in customers. This can be reinforced by advertisements that also inspire trust and confidence (Coetzee et al. 2013; De Jagger \& Du Plooy 2007; Zeithaml et al. 2012). With regard to empathy, service providers should focus on providing personalised attention to customers. This involves opening up communication channels so that customers can easily interact with the firm. As they interact with the firm, customers can present their grievances in order that management can work to address particular issues.

Generally, there is no difference between residential and business customers in terms of the effect of perceived service quality on customer satisfaction. However, a difference was found as regards the empathy dimension. The effect of empathy on customer satisfaction is stronger for business than for residential customers. Telecommunications service providers in developing and transitional countries such as Zimbabwe are advised accordingly. To satisfy their customers through provision of quality services, there is no need to segment their target markets based on the customer category (residential or business). However, firms should commit more effort toward managing empathy for residential than for business customers to achieve the same level of customer satisfaction. This is because the effect of empathy on customer satisfaction is stronger in the business than the residential customer segment.

\section{Limitations and recommendations for future research}

Although the present findings make some contributions to knowledge, the article is not without limitations. The study sample was small and limited to customers in Harare. Only a single sector, fixed-line telecommunications, was considered. This makes it difficult to generalise the findings to other sectors. Therefore, it is recommended that a more representative sample be considered in future studies. Other sectors may also be considered. Further studies may also be conducted in other countries to validate the present findings. Given the results of the article, other well-established relationships in services marketing such as customer satisfaction and loyalty may also need to be explored in terms of residential versus business customers.

\section{Acknowledgements Competing interests}

The authors declare that they have no financial or personal relationships which may have inappropriately influenced them in writing this article.

\section{Authors' contributions}

C.M. was the research project leader and responsible for the choice and development of methodology, data analysis and discussion as well as writing of the paper. D.M. was responsible for data collection, analysis and discussion.

\section{References}

Aghdaie, S.F.A. \& Faghani, F., 2012, 'Mobile banking service quality and customer satisfaction (application of SERVQUAL model)', International Journal of Management and Business Research 2(4), 352-361.

Agyapong, G.K.Q., 2011, 'The effect of service quality on customer satisfaction in the utility industry: A case of Vodafone (Ghana)', International Journal of Business and Management 6(5), 203-210. http://dx.doi.org/10.5539/ijbm.v6n5p203

Almossawi, M.M., 2012, 'Customer satisfaction in the mobile telecom industry in Bahrain: Antecedents and consequences', International Journal of Marketing Studies 4(6), 139-156. http://dx.doi.org/10.5539/ijms.v4n6p139

Arasli, H., Katircioglu, S.T. \& Mehtap-Smadi, S., 2005, 'A comparison of service quality in the banking industry: Some evidence from Turkish and Greek-speaking areas in Cyprus', International Journal of Bank Marketing 23(7), 508-526. http://dx.doi. org/10.1108/02652320510629881

Bashir, M.S., Machali, M.M. \& Mwinyi, A.M., 2012, 'The effect of service quality and government role on customer satisfaction: Empirical evidence of microfinance in Kenya', International Journal of Business and Social Science 3(14), 312-319.

Baumann, C., Burton, S., Elliot, G. \& Kehr, H.M., 2007, 'Prediction of attitude and behavioural intentions in retail banking', International Journal of Bank Marketing 25(2), 102-116. http://dx.doi.org/10.1108/02652320710728438

Beneke, J., Hayworth, C., Hobson, R. \& Mia, Z., 2012, 'Examining the effect of retail service quality dimensions on customer satisfaction and loyalty: The case of the supermarket shopper', Acta Commercii 2012, 27-43.

Brennan, R., Canning, L. \& McDowell, R., 2011, Business-to-business marketing, 2nd edn., SAGE, London.

Bryman, A., 2008, Social research methods, 3rd edn., Oxford University Press, New York.

Coetzee, J., Van Zyl, H. \& Tait, M., 2013, 'Perceptions of service quality by clients and contact-personnel in the South African retail banking sector', Southern African Business Review 17(1), 1-22. 
Cronin, J. \& Taylor, S., 1992, 'Measuring service quality: A re-examination and extension, Journal of Marketing 56(3), 55-68.

Cronin, J.J. \& Taylor, S.A., 1994, 'SERVPERF versus SERVQUAL: Reconciling performance-based and perceptions-minus-expectations measurement of servic quality', Journal of Marketing 58(1), 125-131. http://dx.doi.org/10.2307/1252256

De Jagger, J. \& Du Plooy, T., 2007, 'Measuring tangibility and assurance as determinants of service quality for public health care in South Africa', Acta Commercii 2007 96-111.

De Jagger, J.W. \& Du Plooy, A.T., 2006, 'Student's expectations of service quality in tertiary education: A comparison between prospective and current students, Acta Commercii 2006, 10-19.

Ellis, N., 2011, Business to business marketing: Relationships, networks and strategies, Oxford University Press, Oxford.

Field, A., 2009, Discovering statistics using SPSS, 3rd edn., SAGE, London.

Fornell, C. \& Larcker, D.F., 1981, 'Evaluating structural equation models with unobservable variables and measurement error', Journal of Marketing Research 18(1), 39-50. http://dx.doi.org/10.2307/3151312

Ha, H-Y. \& Son, H-Y., 2014, 'Investigating temporal effects of risk perceptions and satisfaction on customer loyalty', Managing Service Quality 24(3), 252-273. http://dx.doi.org/10.1108/MSQ-07-2013-013

Homburg, C., Koschate, N. \& Hoyer, W.D., 2005, 'Do satisfied customers really pay more? A study of the relationship between

Hutt, M.D. \& Speh, T.W., 2012, Business marketing management, 11th edn., Cengage Learning, Mason, O.H.

Iyer, K.N.S., Germain, R. \& Frankwick, G.L., 2004, 'Supply chain B2B E-commerce and time-based delivery performance', International Journal of Physical Distribution \& Logistics Management 34(8), 645-661, http://dx doi.org/ 0557776

Kabweza, L.S.M., 2010, An overview of Zimbabwe's telecommunications - POTRAZ presentation, viewed 15 December 2015, from http://www.techzim.co. zw/2010/03/zimbabwe-telecoms-overview/

Khuhro, R.A., Azahr, S.M., Bhutto, N.A., Sarki, I.H. \& Shaikh, I.A., 2011, 'Customer satisfaction in telecom industry after mobile number portability', Interdisciplinary Journal of Contemporary Research in Business 3(8), 840-846.

Kotler, P., Armstrong, G., Wong, V. \& Saunders, J., 2008, Principles of marketing, 5th edn., Pearson Education Limited, Essex.

Kumar, M. \& Sareen, M., 2011, Trust and technology in B2B E-commerce: Practices and strategies for assurance, IGI Global, USA, Philadelphia.

Kuo, Y-F., Wu, C-M. \& Deng, W-J., 2009, 'The relationships among service quality, perceived value, customer satisfaction, and post-purchase intention in mobile value-added services', Computers in Human Behavior 25(2009), 887-896. http://
dx.doi.org/10.1016/j.chb.2009.03.003
Lee, M.C. \& Hwan, I.S., 2005, 'Relationships among service quality, customer satisfaction and profitability in the Taiwanese banking industry', Internationa Journal of Management 22(4), 635-648.

Lovelock, C. \& Wirtz, J., 2011, Services marketing: People, technology, strategy, 7th edn., Pearson Education Limited, Essex.

Moolman, H.J., 2011, 'Restaurant customer satisfaction and return patronage in a Bloemfontein shopping mall', Acta Commercii 2011, 129-146.

Nimako, S.G., Azumah, F.K., Donkor, F. \& Veronica, A.B., 2010, 'Overall customer satisfaction in Ghana's mobile telecommunication network: Implications for management and policy', ATDF Journal 7(3/4), 35-49.

Noko, J., 2011, 'Dollarization: The case of Zimbabwe', Cato Journal 31(2), 339-365.

Olorunniwo, F., Hsu, M.K. \& Udo, G.J., 2006, 'Service quality, customer satisfaction, and behavioral intentions in the service factory', Journal of Services Marketing 20(1), 59-72. http://dx.doi.org/10.1108/08876040610646581

Quaddus, M. \& Hofmeyer, G., 2007, 'An investigation into the factors influencing the adoption of B2B trading exchanges in small businesses', European Journal of Information Systems 1(16), 202-215. http://dx.doi.org/10.1057/palgrave.ejis. 3000671

Seth, N., Deshmukh, S.G. \& Vrat, P., 2005, 'Service quality models: A review', International Journal of Quality and Reliability Management 22(9), 913-949. http://dx.doi.org/10.1108/02656710510625211

Sikwila, M.N., 2013, 'Dollarization and the Zimbabwe's economy', Journal of Economics and Behavioral Studies 5(6), 398-405.

Stokes, D. \& Lomax, W., 2008, Marketing: A brief introduction, Thompson Learning, London.

Tam, J.L.M., 2004, 'Customer satisfaction, service quality and perceived value: An integrative model', Journal of Marketing Management 20(7-8), 897-917.

Thaichon, P., Lobo, A. \& Mitsis, A., 2014, 'An empirical model of home internet services quality in Thailand', Asia Pacific Journal of Marketing and Logistics 26(2), 190-210. http://dx.doi.org/10.1108/APJML-05-2013-0059

Wang, I.M. \& Shieh, C.J., 2006, 'The relationship between service quality and customer satisfaction: The example of CJCU library', Journal of Information and Optimization Sciences 27(1), 193-209. http://dx.doi.org/10.1080/02522667.2006. 10699686

Zeithaml, V.A., Bitner, M.J. \& Gremler, D.D., 2012, Service marketing: Integrating customer focus across the firm, 6th edn., McGraw-Hill Education, New York, N.Y.

Zikmund, W.G., Babin, B.J., Carr, J.C. \& Griffin. M., 2010, Business research methods, 8th edn., Cengage Learning, Mason, O.H. 


\section{Appendix 1}

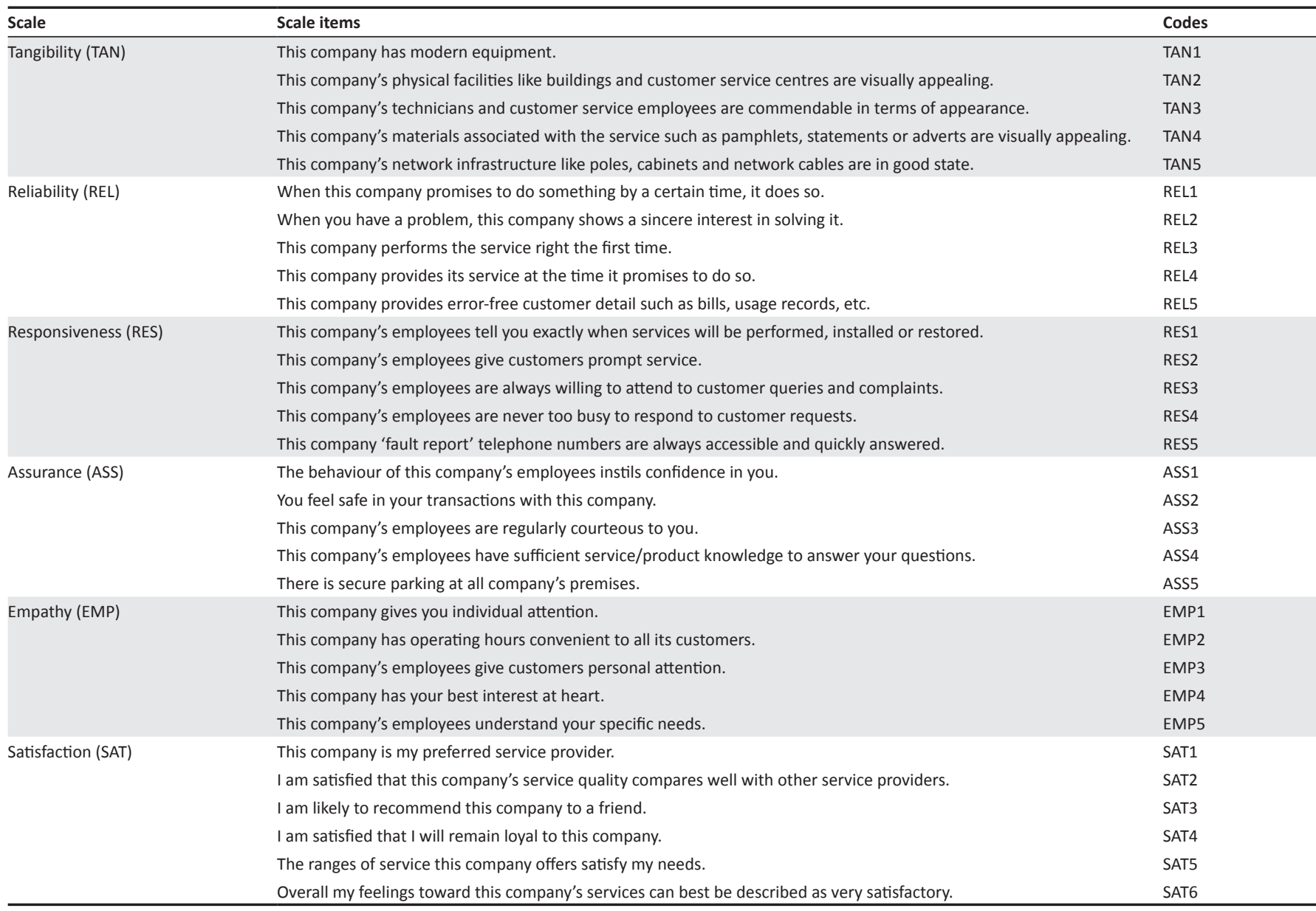

Source: Adapted from Coetzee et al. (2013), Cronin and Taylor (1992, 1994), Ha and Son (2014), Kuo et al. 2009; Olorunniwo et al. 2006; Tam (2004); Thaichon et al. (2014) and Wang and Shieh (2006) 